\title{
脳卒中易発症性高血圧自然発症ラットの 虚血性脳障害に対するセサミンの予防効果
}

\author{
村上哲 男*, 吉 栖 肇*, 伊藤 浩 行** \\ - 近幾大学農学部食品栄掌科 \\ ** 近畿大学高血圧研究所
}

\author{
Prophylactic Effects of Sesamin on Ischemic Cerebral Injury in \\ Stroke-Prone Spontaneously Hypertensive Rats \\ Tetsuo MURAKAMI,* Hajime YOSHIZUMI* and Hiroyuki ITO** \\ -Department of Food Science and Nutrition, Faculty of Agriculture, \\ Kinki University, Nara 631 \\ - Research Institute of Hypertension, Kinki University, Osaka 589
}

\begin{abstract}
Nippon Eiyō Shokuryō Gakkaishi (J. Jpn. Soc. Nutr. Food Sci.) 48, 189 193 (1995)
As part of a basic study on the prevention of ischemic cerebral injury, sesamin $(5 \mathrm{~g} / \mathrm{kg}$ Funabashi SP diet) was administered to stroke-prone spontaneously hypertensive rats (SHRSP) for 8 weeks from 8 weeks of age, and pathological and biochemical changes in the cerebral cortex were examined and compared with those in normotensive Wistar-Kyoto rats (WKY). In the control SHRSP, cerebral softening was found in 4 of 8 rats $(50 \%)$, whereas no pathological changes were evident in sesamin-treated rats. In control SHRSP, the uric acid content of the cerebral cortex was extremely high in comparison with that in control WKY, but it was significantly lower $(p<0.05)$ in sesamin-treated SHRSP. On the other hand, superoxide dismutase (SOD) activity was lower $(p<0.05)$ and $\mathrm{Na} / \mathrm{K}$.ATPase was higher $(p<0.05)$ in sesamin-treated SHRSP than in WKY. These results indicate that lipid peroxidation caused by free radicals is an important factor in ischemic cerebral injury, and that sesamin plays an important role in the scavenging of free radicals, thus preventing cerebral softening in SHRSP.
\end{abstract}

Key Words cerebral cortex, free radical, uric acid, superoxide dismutase, sesamin, SHRSP, WKY.

(Received December 14, 1994)

脳血管障害の病理発生に関しては, 実験的にも臨床的 にも, 多くの研究がなされているが, 虚血による神経細 胞障害の発生機序に関しては, 不明の点が数多く残され ている。Demopoulos ら”が虚血性脳障害において, フ リーラジカルの形成とそれに基づく脂質過酸化が重要な 役割を演じていることを示して以来, 脳におけるフリー ラジカル障害について多くの研究がなされている。 Kanemitsu ら ${ }^{2)}$ は砂ネスミの絰頞動脈を結柋した脳虚 血モデルにおいて，尿酸値が異常に上昇することを見い たしし,フリーラジカルの産生源としてキサンチンーキサン チンオキシダーゼ系の関与を報告している。しかし, こ のモデルは急性のしかも一過性の虚血であり, ヒトの場

" 个631 奈良市中町 3327-204

** 个589 大阪狭山市大野東 377-204
合のような慢性かつ持続性の虚血の場合とは病態が異

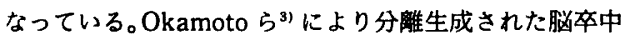
易発症性高血圧自然発症ラット (SHRSP) は, 高血圧の 進展とともにその $95 \%$ 以上が脳卒中病変を発症するも ので，ヒトの本態性高血圧およびそれによる脳卒中（脳 軟化, 脳出血）のモデルとして最適のものであり，世界 各国で広く用いられている。われわれは4, SHRSP を用 いて食餌因子による脳卒中病変の予防や治療に関する基 礎的な実験を行い, 高血圧確立期からでも魚肉をタンパ ク源とした飼料の投与で血圧の低下がみられないにもか かわらず脳卒中病変の発生率が低下し, 生存日数の延長 がみられることを報告した。その機序として, 脂質過酸 化の抑制や, 動脈壁エラスチンの減少の抑制あるいは血 漿レンン活性や組織内アンギオテンシン I 変換酵素活性 の低下等が考えられた (5) 7)。Ito ら 
買における病䈍を生化学的に検索し, 高血圧発症後の SHRSP の大脳皮實では脂質過酸化の妄進および細胞膜 関連酵素の異常がみられることを報告している。これら の結果は, SHRSPにおける虚血性脳障害にはフリーラ ジカルによる細胞膜の脂質過酸化が重要な原因であり, 食鲆因子の改善によりある程度予防できることを示唆し ている。そこで, 今回の実検ては高血压およびその続発

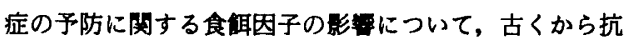
酸化能を有することが知られているゴマに注目し，その 微量成分の一種であるリグナン類のセサミンの虚血性神 経障害抑制作用を検討した。

\section{実 験 方 法}

\section{1. 材料およひ飼料}

セサミンは, サントリー掬より提供されたものを使用 した。このセサミンは精製ゴマ油から調製されたもので， (+)-セサミンが $60 \%$ と（一)-エピセサミンが $40 \%$ の混

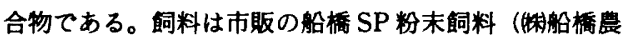
場）を使用した。この飼料組成であるが, 動物性タンパ ク質源にはホワィトフィッシュミールと脱脂粉乳, 植物 性タンパク質源には脱脂大豆を使用しており, 水分が $7.0 \%$, 粗タンパク㙺 $20.8 \%$, 粗脂肪 $4.5 \%$, 粗䄉 維 $3.4 \%$, 粗灰分 $5.7 \%$, 可溶性無窒素物 $58.6 \%$ である。

\section{2. 実検勤物およひ飼育条件}

研究室で系統維持している8 週砱の雄性 SHRSP と 対照として同週撂の正常王のWistar-Kyotoラット （WKY）を用いた。SHRSPは系統により血圧の上昇や 生存日数が異なる。本実倹には血圧上昇が急激で, 寿命 の短い系統 (SHRSP $\mathrm{A}_{3}$ 系) を使用した。1 群 8 匹とし おのおのを実倹群と対照群に分け，4匹ずつステンレス 製咱育ヶージに入れて飼育した。対照群には上記の市販 粉末飼料を，実験群にはこれに粉末セサミンを $0.5 \%$ の 割合で混合した飼料を与えた。ラットは室温 $23 \pm 1^{\circ} \mathrm{C}$, 湿 度 $55 \pm 5 \%$ 設定し, 12 時間ごとの明暗切り替え条件

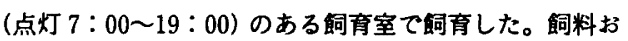
よび飲料水は自由摄取させた。実験期間中, 血圧と体重 は毎週 1 回測定した。血圧は無麻酔下で尾動脈圧を Tailcuff 法 (モデル：KN-210-1, 夏目製作所)により測定し た。16 週龄（投与 8 週間後）に浅クロロフォルム麻酔下 に断頭屠殺した。ただちに開頭を行い, 脳重量の測定と 肉眼的観察により, 脳卒中病変の有無を検案した。その 後大脳皮質を分離した。

3. スーパーオキシドディスムターゼ（SOD）活性の 測定

分離した大脳皮質の右大脳皮質後半部を $0.25 \mathrm{M} シ ョ$ 糖-10 mMトリス緩街液 (pH 7.5) 中でホモゲナイズ， 遠心分離後 $\left(10,000 \mathrm{rpm}, 10 \mathrm{~min}, 4^{\circ} \mathrm{C}\right)$ その上清を $\mathrm{SOD}$
活性の粗醇素液とした。SOD 活性の測定は Oyanagui の 原法9)にしたがって, 垔硝酸法により測定した。本法はキ サンチンーキサンチンオキシダーゼによりヒポキサンチ ンから生じるスーパーオキシドアニオンをジアソ化合物 として捕えるもので, 生成されるスーパーオキシドアニ オンを $50 \%$ 阻害する量を試料の希釈系列から計算し, nitrite unit（NU）として表した。本法は, チトクローム $c$ 法に比へ, 2.89 倍の感度が認められた。

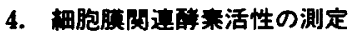

細胞膜の機能障害を表す指標として，代表的な細胞膜 闺連醉素である Na/K-ATPase活性をLamers and Stinis の方法 ${ }^{10)} に$ 従って, 分光光度法により測定した。 なお，粗醅素液はSOD 活性の測定用に調製したものを 使用した。

\section{5. 組镨中の尿酸の測定}

分離した大脳皮賈の左大脳皮質後半部を $2 \%$ メリン 酸ソーダ中でホモゲナイスし, 遠心分離後 $(10,000 \mathrm{rpm}$, $\left.10 \mathrm{~min}, 4^{\circ} \mathrm{C}\right)$, その上清中の尿酸值を測定した。組織中の 尿酸值は, Kanemitsu ら ${ }^{2)}$ の方法にしたがって, HPLC ED system を用いて定量した。なおカラムの長さは $250 \times 4.0 \mathrm{~mm}$ とし, Chemco ODS-5-H (Chemco, Tokyo)を充填した。elution bufferにはPIC (Waters, Millipore Corporation, MA, USA) を用いた。

\section{6. 統敦処理}

実験データは平均値士標準誤差で表した。結果は比較 すべき数值の等分散性を検定後, Student's $t$-testによっ て，また，等分散性を示さなかったものについては， Welch's $t$-test により有意差を判定した。なお，検定に は, MUSCOT 統計解析プログラム (YUKMS Co.) を 使用し, $p<0.05$ を有意とした。

\section{結果}

\section{1. 血圧およひ体臬}

Fig. 1 は, 各群の血圧と体重の変化を示している。 WKYで, 実験群と対照群はほほ同様の血圧值を示し, 両者の間に有意な差はみられなかった。SHRSPでは対 照群の血圧はすでに $270 \mathrm{mmHg}$ 近くまで上昇している が,セサミン投与群でも対照群とほほ同様の血圧を示し, 血圧上昇抑制作用は認められなかった。一方，体重に関 しても,WKYても SHRSPても，実験群と対照群は同様 の值を示し，成長に対する影锌は認められなかった。

\section{2. 脳豆至およひ睬卒中病变の発症}

Table 1 は各群における脳重量と脳卒中病変の発症率 を示している。WKYては両群ともに病変はまったく認 められず, 脳重量にも有意な差は認められなかった。一 方, SHRSP では両群の間に有意の差はみられなかった が, 実験群は対照群に比へ低値を示す傾向がみられた。 
Table 1. Brain weight and incidence of stroke lesion of SHRSP and WKY administered sesamin from 8 weeks of age.

\begin{tabular}{llcccc}
\hline Strain & Diets & $\begin{array}{c}\text { Body weight } \\
(\mathrm{g})\end{array}$ & $\begin{array}{c}\text { Blood pressure } \\
(\mathrm{mmHg})\end{array}$ & $\begin{array}{c}\text { Brain weight } \\
(\mathrm{g})\end{array}$ & $\begin{array}{c}\text { Incidence of } \\
\text { stroke } \\
(\%)\end{array}$ \\
\hline WKY & Control(8) & $299 \pm 18$ & $140 \pm 2$ & $1.83 \pm 0.08$ & $0(0 / 8)^{2}$ \\
& Sesamin(8) & $295 \pm 16$ & $145 \pm 5$ & $1.74 \pm 0.15$ & $0(0 / 8)$ \\
\hline SHRSP & Control(8) & $255 \pm 13$ & $267 \pm 7$ & $2.02 \pm 0.09$ & $50(4 / 8)$ \\
& Sesamin(8) & $252 \pm 4$ & $260 \pm 7$ & $1.80 \pm 0.08$ & $0(0 / 8)$ \\
\hline
\end{tabular}

Results are expressed as mean \pm SE. ${ }^{1}$ Number of rats examined, ${ }^{2}$ Rats with stroke/total number of rats.
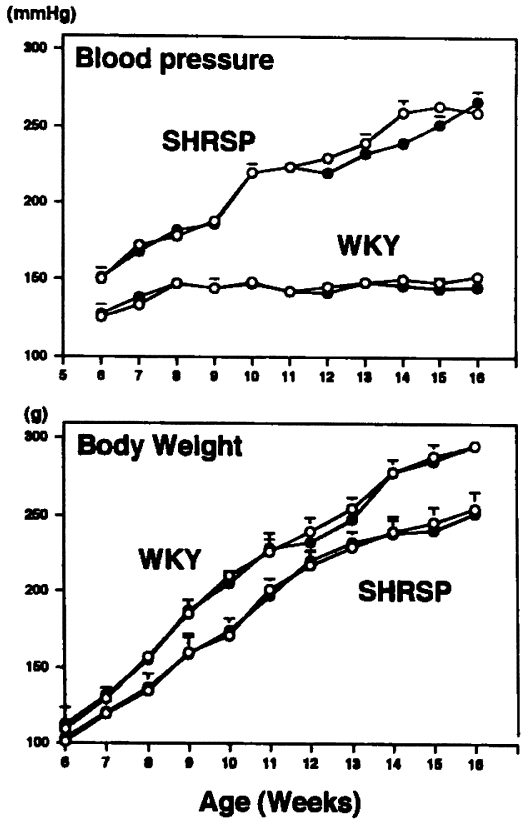

Fig. 1. Changes of blood pressure and body weight of SHRSP and WKY administered sesamin.

Effects of sesamin diet ( $0.5 \% /$ Funabashi-SP diet) from 8 weeks of age on blood pressure in SHRSP and WKY. The values are expressed as the mean $\pm \mathrm{SE}$ of 8 rats. The vertical bars indicate the s.e.m. $O$, control group $(n=8) ; \bullet$, sesamin group $(n=8)$.

とくに,対照群では脳重量が $2 \mathrm{~g}$ を越えるものが 8 例中 4 例にみられこれらの大脳皮質には肉眼的にも明らかな 軟化巣が認められた。しかし, セサミンを投与した群で は脳重量が $2 \mathrm{~g}$ を越えるものはみられず, 脳卒中病変も まったく認められなかった。

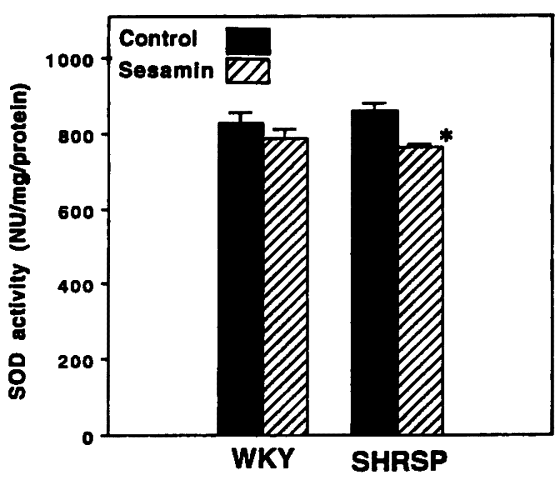

Fig. 2. Effects of sesamin on SOD activity in cerebral cortex of SHRSP and WKY.

Effects of sesamin diet (0.5\%/Funabashi-SP diet) from 8 weeks of age on SOD activity in cerebral cortex of SHRSP and WKY. The values are expressed as the mean $\pm \mathrm{SE}$ of 8 rats. Asterisks indicate significant difference from the control $(p<0.05)$. The vertical bars indicate the s.e.m.

\section{SOD 活性および尿酸佂}

Fig. 2 は各群の大脳皮質におけるSOD活性を示して いろ。SHRSP の対照群はWKY の対照群とほほ同様の 活性を示し, 両者の間に有意の差はみられなかった。ま た, WKYでは実験群と対照群の間に有意の差はみられ なかったが, SHRSPでは実験群は対照群に比へ有意に 低值を示した。一方, Fig. 3 にみられるように大脳皮質 における尿酸值を比較するとSHRSP 対照群は著しい 上昇を示しており，WKYの対照群に比へ明らかに高値 を示した。WKYではセサミン投与による影響はみられ なかったが, SHRSP の実験群では尿酸値の上昇はみら れず，対照群に比へ有意に低值であった。

\section{4. $\mathrm{Na} / \mathrm{K}-\mathrm{ATPase}$ 活性}

Fig. 4 は各群における Na/K-ATPase 活性の比較を 示している。SHRSP の対照群の活性はWKY の対照群 に比へ低値を示す傾向がみられたが，有意な差ではな 


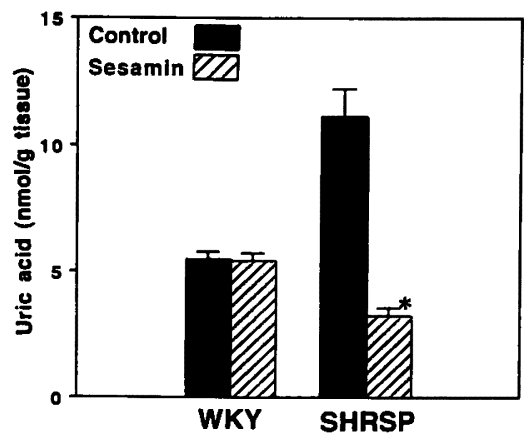

Fig. 3. Effects of sesamin on uric acid level in cerebral cortex of SHRSP and WKY.

Effects of sesamin diet (0.5\%/Funabashi-SP diet) from 8 weeks of age on uric acid level in cerebral cortex of SHRSP and WKY. The values are expressed as the mean $\pm \mathrm{SE}$ of 8 rats. Asterisks indicate significant difference from the control $(p<0.01)$. The vertical bars indicate the s.e.m.

かった。WKYでは実験群も対照群も同様の活性を示 したが, SHRSPでは実験群は対照群に比べ有意に高い 活性を示した。

\section{考察}

高血圧が長期間持続すると, 動脈壁の肥厚や壊死など

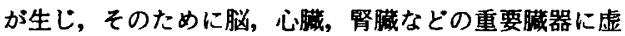
血性の変化が生じることがよく知られている。とくに中 枢神経系は虚血あるいは低酸素の影挴を受けやすく，神 経細胞は容易に変性・壤死に陥り, 最も重症の場合には 脳卒中病変(脳出血あるいは脳軟化)が生じる。したがっ て, 虚血による細胞障害のメカニズムを解明することは, 脳卒中の予防あるいは治療にとってきわめて重要な課題 であるが，いまだ十分に明らかにされていない。虚血に よる脳障害の発生に関してフリーラジカルが重要な役割 を演じており, それによる脂質過酸化が病因として重要 であることが, 数々の実験的研究により明らかにされて いる211112)が，一方では，その生理的意義を疑問視する報 告もみられる ${ }^{13)}$ 。

われわれはSHRSP の赤血球におけるグルタチオン ペルオキシダーゼ (GSH-Px) 活性の変動を経時的に測定 し, 醅素活性の低下と脳卒中病変の発症時期がよく一致

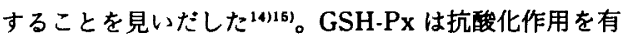
する代表的な醳素であることから，生体内における抗酸 化能の低下が組織障害を惹き起こすことが推測された。 これらの結果は, 高血圧による慢性的な持続性虚血に基 づく脳障害の病因として, フリーラジカルによる脂質過

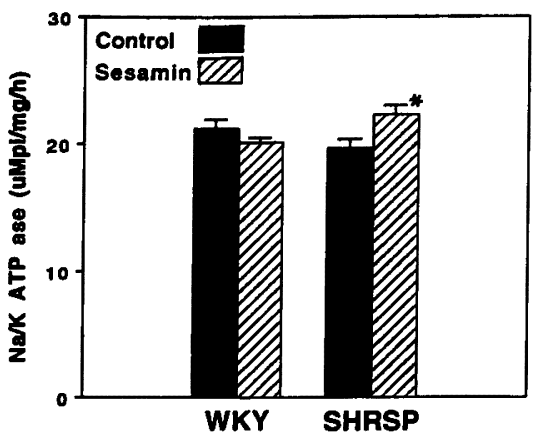

Fig. 4. Effects of sesamin on $\mathrm{Na} / \mathrm{K}$ ATPase activity in cerebral cortex of SHRSP and WKY.

Effects of sesamin diet (0.5\%/Funabashi-SP diet) from 8 weeks of age on $\mathrm{Na} / \mathrm{K}$ ATPase activity in cerebral cortex of SHRSP and WKY. The values are expressed as the mean $\pm \mathrm{SE}$ of 8 rats. Asterisks indicate significant difference from the control $(p<0.05)$. The vertical bars indicate the s.e.m.

酸化が重要な役割を有していることを示している。そこ で今回の実匼では，抗酸化能を有することが知られてい るゴ油に注目し，その微量構成成分の一つであるセサ ミンを投与し，脳障害に及沽す影稫を検討した。正常血 圧のWKYではセサミン投与による著しい影辢はみら れなかったが, SHRSPでは対照群で脳卒中病変の認め られるものがあり, かつ脳重量の増加がみられ,これら のラットでは尿酸值は著しく高值であった。尿酸はキサ ンチンーキサンチンオキシダーゼ系の最終産物であり,そ の生成過程において多量のスーパーオキシドアニオンが 生じる(6)ことから,これらの結果は, SHRSP の大脳皮 質における虚血性病変の発症には, キサンチンオキシ ダーゼ系に由来するスーパーオキシドおよびそれから生 成される過酸化水点やヒドロキシラジカルなどが重要な 障害因子として作用していることを示唆している。した がって, SHRSP の大脳皮質てはこれらのフリーラジカ ルにより,内皮細胞障害が生じ透過性が亢進するととも に, 神経細胞そのものも障害されると考えられる。しか し，尿酸にはラジカルスカベンジャーとしての作用が認 められており, 虚血による脳障害の病態はきわめて複雑 であると考えられる。一方, セサミン投与群では脳重量 の增加はなく, 脳卒中病変はまったく認められず, 虚血 性脳障害は明らかに防止された。このようなラットでは 大脳皮質における尿酸值は明らかに低值であることか ら，セサミン投与によりヒポキサンチンの分解が抑制さ れ, フリーラジカルの生成が防止されていることが推湘 
される。事実, セサミンを投与した SHRSP の大脳皮貿 ては細胞膜障害のマーカーである $\mathrm{Na} / \mathrm{K}$-ATPase 活性 は対照群に比へ有意に高く, 細胞障害が軽度であること が示された。このようなセサミンの虚血性脳障害の発症 防止の機序に関しては, キサンチンオキシダーゼ系の抑 制あるいはラジカル捕捉作用が考えられる。キサンチ ンーキサンチンオキシターーゼ系に対するセサミンの作用 は, 文献的にも報告はなく, また, 今回の実験からも未 だ不明である。セサミンには抗酸化作用が認められない ことが知られている(7)18) ことから，セサミンそのものに ラジカル捕捉作用があることが推測される。今回の実験 では，セサミンを投与したSHRSP ではSOD活性が低 值であった。SOD は代表的な消去系醭素であり，セサミ ン投与群における活性の低下はネガティフフィードバッ ク機構によると考えられる。事実, 浅見ら ${ }^{19)}$ はセサミン に OH ラジカルに対する捕捉活性が認められることを 報告している。したがって, 今回の実験の結果は, セサ ミンを投与されたSHRSPの大脳皮質においては, 虚血 により生じるフリーラジカルが速やかに捕捉されること により, 内皮細胞障害および神経細胞障害の発生が防止 されることを示している。これはセサミン投与 SHRSP では, 尿酸值の異常な上昇が抑制されていることからも, 推測される。今回の実験では, 虚血局所（大脳皮質）に おけるラジカル産生と消去についてのみ検討した。一般 にフリーラジカルの産生源としてはキサンチンオキシタ 一ゼ系の他に好中球をはじめとする炎症性細胞や, 練胞 内におけるミトコンドリアなどがよく知られており,こ れらの関与も当然考えられなければならない。また，七 サミンの作用についても局所における作用とともに血液 や腎機能に対する作用など全身的な影盤も考察する必要 があり今後に残された課題である。

\section{要 約}

8 週龄の SHRSP にセサミン (市販粉末飼料中に $0.5 \%$ 添加）を 8 週間投与し, 血圧や体重および大脳皮質におけ るフリーラジカル障害に及ほす影䈉を検討した。

1）WKYでも SHRSPでも, 血圧や体重への影整は 認められなかった。

2）SHRSPの対照群では脳重量の増加がみられ，半 数に脳軟化巣が認められたが, セサミン投与群では脳重 量の増加はなく, 脳卒中病変の発生も認められなかった。

3） SHRSP の大脳皮質では尿酸値の著しい上昇がみ
られたが,これはセサミン投与により明らかに抑制され た。

4）SHRSP のセサミン投与群では SOD 活性は対照 群に比べ低値であった。

5）SHRSPのセサミン投与群ては $\mathrm{Na} / \mathrm{K}$-ATPase 活性が対照群に比べ高値であった。

以上の結果より, 七サミンはSHRSP の大脳皮質にお いてキサンチン-キサンチンオキシダーゼ系で産生され るフリーラジカルを速やかに捕捉することにより, 虚血 による障害を防止すると考えられる。

\section{文献}

1) Demopoulos, H., Flamm, E., Seligman, M., Power, R., Pietronigro, D. and Ransohoff, J. : Oxygen and Physiological Function (Joebsis, F.F., ed.), 491 (1977), Professional Information Library (Dallas)

2) Kanemitsu, H., Tamura, A., Kirino, T., Oka, H., Sano, K., Iwamoto, T. and Yoshimura, M. : Brain Res., 499, 367 (1989)

3) Okamoto, K., Yamori, Y. and Nagaoka, A. : Circ. Res., 34/35 (suppl. I), I43 (1974)

4) Murakami, T., Tsuji, A., Shigeoka, S. and Iizuka, Y.: Jpn. Heart J., 28, 645 (1987)

5）村上哲男, 辻 章夫, 山本和夫, 岡本耕造 : 栄食誌, 45, 129 (1992)

6）村上哲男, 辻 章夫, 山本和夫, 岡本耕造：栄食誌, 45, 139 (1992)

7) Murakami, T., Soga, M., Mitsunaga, T., Yoshizumi, H. and Ito, H. : Clin. Exp. Pharmacol. Physiol., 21, 453 (1994)

8) Ito, H., Torii, M. and Suzuki, T. : Int. J. Biochem., 12, 1801 (1993)

9) Oyanagui, Y.: Anal. Biochem., 142, 290 (1984)

10) Lamers, J.M. and Stinis, J.T. : Biochim. Biophys. Acta, 640, 521 (1981)

11) Betz, A.R., Randall, J. and Martz, D. : Am. J. Physiol., 260, H563 (1991)

12) O'Neill, R.D. : Brain Res., 507, 267 (1990)

13) Schultz, V. and Lowenstein, J. M. : J. Biol. Chem., 251, 485 (1976)

14) Murakami, T., Soga, M. and Yoshizumi, H. : Jpn. Heart J., 33, 530 (1992)

15) Murakami, T., Takemori, K., Takeda, T. and Yoshizumi, H. : Clin. Exp. Pharmacol. Physiol., 22, (1995) in press

16) McCord, J.M. : N. Engl. J. Med., 312, 159 (1985)

17) Fukuda, Y., Osawa, T., Namiki, M. and Ozaki, T. : Agric. Biol. Chem., 49, 301 (1985)

18）並木满夫, 小林貞作 (編)：Jマの科学, 180 (1989), 朝倉䡒店 (東京)

19）浅見純生, 秋元健吾, 阿部圭一，赤松 㣚，小西恭子, 清水 昌, 菅野道廣, 山田英明: 農化, 67, 3 (1993)

(1994 年 12 月 14 日受理) 